\title{
Efficacy of Cosmetic Materials Using Aronia melanocarpa Leaf Extracts
}

\author{
Jung Min Lee, Min Jeong Ryu* \\ Department of Cosmetology Science, Nambu University, Gwangju, Korea
}

\author{
*Corresponding author: Min Jeong Ryu, \\ Department of Cosmetology Science, \\ Nambu University, 23 advanced Jungang-ro, \\ Gwangsan-gu, Gwangju 62271, Korea \\ Tel.: +82629700137 \\ Fax: +82629726200 \\ Email: jemine0806@hanmail.net
}

Received July 15, 2017

Revised January 8, 2018

Accepted January 10, 2018

Published June 30, 2018

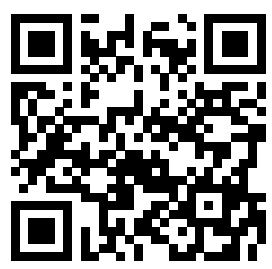

\begin{abstract}
Purpose: To determine the anti-oxidant, whitening, anti-inflammatory and collagen synthesis effects of Aronia melanocarpa ( $A$. melanocarpa) leaf extracts for use as cosmetic ingredients. Methods: Ethanol and hot water leaf extracts of $A$. melanocarpa were used as test samples. Total polyphenol and flavonoid contents of the leaf extracts were quantified. The anti-oxidant activity of leaf extracts was measured using the 1,1-diphenyl-2-picrylhydrazyl (DPPH) radical scavenging assay. The whitening effect of leaf extracts was measured in the mouse melanoma cell line B16F10. The inhibitory effect of leaf extracts on the production of nitric oxide (NO) was measured using lipopolysaccharide (LPS)-stimulated RAW 264.7 mouse macrophages. The amount of procollagen synthesized with and without leaf extracts was measured in human dermal fibroblasts (HDF) using ELISA. Results: The total polyphenol contents in the ethanol and hot water leaf extracts of $A$. melanocarpa were $167.46 \pm 1.03 \mu \mathrm{g} / \mathrm{mL}$ and $79.04 \pm 1.01 \mu \mathrm{g} / \mathrm{mL}$, respectively, and the total flavonoid contents were $105.15 \pm 1.22 \mu \mathrm{g} / \mathrm{mL}$ and $52.21 \pm 1.13 \mu \mathrm{g} / \mathrm{mL}$, respectively. The DPPH radical scavenging effect of ethanol extracts was higher than that of hot water extracts. In the mouse melanoma cell line B16F10, the tyrosinase inhibitory activity and melanin inhibition rate using $100 \mu \mathrm{g} / \mathrm{mL}$ ethanol extracts and 100 $\mu \mathrm{g} / \mathrm{mL}$ hot water extracts were $21 \%$ and $24 \%, 18 \%$ and $18 \%$, respectively. The tyrosinase inhibitory activity and melanin inhibition induced by $\alpha$-melanocytestimulating hormone $(\alpha-\mathrm{MSH})$ were higher in ethanol extracts than in hot water extracts. The anti-inflammatory effect of ethanol extracts, measured as the inhibition of NO production in LPS-stimulated RAW 264.7 mouse macrophages, was higher than that of hot water extracts. Procollagen synthesis was lower than the positive control group due to the respective $58 \%$ and $41 \%$ increases in procollagen synthesis with the concentration of $200 \mu \mathrm{g} / \mathrm{mL}$. Conclusion: Data showed that $A$. melanocarpa leaf extracts isolated using ethanol exhibited higher anti-oxidant, whitening, antiinflammatory, and collagen synthesis effects than those isolated using hot water. Thus, ethanol leaf extracts can be considered as a candidate for use as ingredients in cosmetic products.
\end{abstract}

Keywords: Aronia melanocarpa, Anti-oxidant, Cosmetics, Whitening, Anti-inflammatory

\section{Introduction}

생활수준의 향상과 노령화 사회의 가속화로 인하여 현대인들 은 외적인 미에 대한 관심이 증가하면서, 화장품 산업은 피부의 미백에 도움을 주는 제품이나 주름개선에 도움을 주는 등 특정 기능이 강조된 기능성 화장품 사업이 크게 성장하고 있다. 이에
따라 식물 등 천연물로부터 얻어지는 기능성 물질들을 원료로서 이용하려는 연구가 활발히 진행되고 있다(Kang et al., 2015).

인간의 피부 색깔은 환경, 인종, 성별 등의 요인과 멜라닌 (melanin), 카로틴 및 헤모글로빈 양과 같은 여러가지 요인에 의 해 결정되지만 피부의 과색소 침착과 관련된 주요한 원인은 표피 내 멜라닌 색소의 이상적 증가에 기인한다(Lee et al., 2005). 
멜라닌은 자연계에 널리 분포하는 페놀류의 고분자 물질로서 단 백질과 검은 색소의 복합체이다. 멜라닌은 인체 내에서 독성물 질에 대한 제거 작용을 하여 세포를 보호하지만 과잉 생산 시 인 체에 기미, 주근깨를 형성하고 피부 노화를 촉진시키며 피부암 을 유발하는 것으로 알려져 있다. 이러한 멜라닌의 생합성 경로 를 보면 tyrosine이 tyrosinase에 의해서 DOPA로 전환되고 다 시 tyrosinase에 의해 DOPA quinone으로 전환되어 최종적으로 멜라닌을 생성하게 된다(Yu et al., 2015).

피부에서 자주 나타나는 변화인 염증(inflammation)은 "균의 감염, 열, 외상, 항원항체 반응 등 생체조직의 기질변화를 초래 하는 침습에 대한 생체의 방어 기전"이라고 정의하고 있다. 염증 이 발생한 부위는 발적, 발열, 동통, 종창, 기능장애와 같은 염증 의 5 대 징후가 발생된다(Hong \& Roh, 2005). 염증반응은 피부 손상 및 노화의 주요 원인이며, 이 과정은 체내 세포 조직에 어떠 한 기질적 변화를 가져오는 침습이 가해질 때, 생체가 재생이나 회복 등을 하기 위한 방어적 반응으로 나타나는 것이다(Park et al., 2015). 이 과정에서 활성산소종(reactive oxygen species) 의 일종인 $\mathrm{NO}$ 는 nitric oxide synthase에 의해 형성 되는 저 분자 라디칼로 기존에 알려진 염증 유발 뿐만 아니라 피부주름 과 melanin 생성에도 중요하게 관여한다는 것이 밝혀지면서 천 연물질을 이용한 $\mathrm{NO}$ 의 생성 저해 연구가 활발히 진행되고 있다 (Lee et al., 2014).

피부 노화는 유전적 요인, 나이가 들어감에 따른 호르몬의 변 화, 대사적 과정 등의 내적 요인과 오염된 환경, 야외활동 증가 에 따른 장기적 자외선 노출과 사회활동에서 오는 스트레스 증가 에 따른 활성산소의 증가 등 다양한 외적 요인이 피부 조직의 콜 라겐과 엘라스틴을 변성시켜 피부 탄력을 저하시키고 피부 주름 을 생성함으로써 피부 노화를 촉진한다(Yang et al., 2016).

아로니아 베리(Aronia melanocarpa)는 장미과의 낙엽 관목 으로 북아메리카에서 자생하며, black chokeberry로도 불린다. 최근에는 한국에서도 재배되고 있다. 아로니아 베리는 주로 안토 시아닌과 같은 폴리페놀류, 플라보노이드 및 탄닌 등을 함유하고 있으며, 천연 항산화제 함량이 많은 기능성 식품으로 언급되고 있다. 안토시아닌 류는 특유의 색 때문에 천연 색소로도 이용되 고 있다(Lee et al., 2013).

아로니아 베리의 연구는 항산화(Hwang \& Thi, 2014) 이외 에도 항알레르기(Jeong, 2008), 주름개선(Kim et al., 2014), 항염증 효과 (Yang et al., 2015), 항비만 활성(Kim et al., 2016), 화장품 소재로서 생리활성 연구(Shin \& Choe, 2015), 아로니아 추출물을 이용한 모발의 염색 특성(Kim \& Park, 2014), 아로니아 첨가에 따른 특성(Lee, 2017; Park et al, 2015) 등이 보고 되었지만, 아로니아 잎에 대한 연구는 미비한 상태이다.

따라서 본 연구에서는 아로니아 잎을 이용하여 피부 미용분야
에서의 항산화, 미백효과, 항염, 콜라겐 합성능을 확인하여 화장 품 기능성 소재로서의 가능성 여부를 확인하고자 한다.

\section{Methods}

\section{1. 시료조제}

본 실험에 사용한 아로니아 잎은 전북 고창(Korea)에서 재배 한 어린 잎을 따서 건조하여 시료로 사용하였다. 에탄올 추출 (70\% ethanol extraction, EE)은 아로니아 잎 $10 \mathrm{~g}$ 에 70\% 에 탄올 $1 \mathrm{~L}$ 를 이용하여 $60^{\circ} \mathrm{C}$ 온도 조건에서 $24 \mathrm{~h}$ 동안 추출하였으 며, 열수 추출(hot water, $\mathrm{HE}$ )은 아로니아 잎 $10 \mathrm{~g}$ 에 증류수 $1 \mathrm{~L}$ 를 이용하여 $90^{\circ} \mathrm{C}$ 온도 조건에서 $24 \mathrm{~h}$ 동안 추출하였다. 추출액 은 여과지(Whatman No. 2; GE Healthcare Life Sciences, USA)를 사용하여 여과하였고, 감압농축기(EYELA N-1000; Tokyo Rikakikai, Japan)를 이용하여 감압농축한 후 동결건조 (FD5508; IlshinBioBase, Korea)하여 냉동 보관하였다.

\section{2. 세포주 및 세포배양}

본 실험에 사용한 B16F10 mouse melanoma 세포, 마우 스의 RAW 264.7 대식세포 그리고 $\mathrm{HDF}$ 세포는 한국세포주 은행(Korea)에서 구입하였다. B16F10 melanoma 세포는 Minimum Essential Medium (MEM; Gibco ${ }^{\mathrm{TM}}$, USA), RAW 264.7 대식세포와 HDF 세포는 Dulbecco's Modified Eagle's Medium (DMEM; $\mathrm{Gibco}^{\mathrm{TM}}$ )에 각각 10\% fetal bovine serum (FBS; Invitrogen, USA)과 1\% streptomycin/penicillin (PEST; Hyclone, USA)을 넣어 배양액으로 각각 $37^{\circ} \mathrm{C}, 5 \% \mathrm{CO}_{2}$ 의 습윤화된 incubator에서 적응시켜 배양하였다.

\section{3. 폴리페놀 함량 분석}

폴리페놀 함량은 Folin \& Denis (1915) 방법에 따라, 추 출물 $(1 \mathrm{mg} / \mathrm{mL}) 50 \mu \mathrm{L}$ 에 증류수 $650 \mu \mathrm{L}$ 넣고 Folin-Denis reagent (Sigma-Aldrich, USA)를 $50 \mu \mathrm{L}$ 가하여 $3 \mathrm{~min}$ 동 안 실온에서 반응시킨다. 반응시킨 후 $10 \%$ sodium carbonate $\left(\mathrm{Na}_{2} \mathrm{CO}_{3}\right.$; Sigma-Aldrich) 포화용액을 $100 \mu \mathrm{L}$ 첨가하고, 최종 볼륨을 $1 \mathrm{~mL}$ 맞추기 위해 증류수 $150 \mu \mathrm{L}$ 넣어 잘 혼 합시켰다. $37^{\circ} \mathrm{C}$ water bath에 $1 \mathrm{~h}$ 반응시킨 후 UV-Vis spectrophotometer (Ultrospec 2000; Pharmacia Biotech, Sweden)을 이용하여 $725 \mathrm{~nm}$ 에서 흡광도를 측정하였다. 표준곡 선은 tannic acid (Sigma-Aldrich) 농도 0-500 $\mu \mathrm{g} / \mathrm{mL}$ 이 되 도록 하고 이로부터 총 폴리페놀 함량을 구하였다.

\section{4. 플라보노이드 함량 분석}

플라보노이드 함량은 추출물 $(1 \mathrm{mg} / \mathrm{mL}) 100 \mu \mathrm{L}$ 에 $1 \mathrm{~mL}$ 
diethylene glycol (Sigma-Aldrich)을 첨가하고, 다시 $1 \mathrm{~N}$ sodium hydroxide (NaOH; Sigma-Aldrich) $100 \mu \mathrm{L}$ 넣 어 잘 혼합시켜 $37^{\circ} \mathrm{C}$ water bath에 $1 \mathrm{~h}$ 반응시킨 후 UV-Vis spectrophotometer을 이용하여 $420 \mathrm{~nm}$ 에서 흡광도를 측정하였 다. 표준곡선은 naringin (Sigma-Aldrich) 농도를 0-300 $\mu \mathrm{g} / \mathrm{mL}$ 되도록 하여 작성하고 이로부터 총 플라보노이드 함량을 구하였다.

\section{DPPH radical 소거작용 측정}

$\mathrm{DPPH}$ (Sigma-Aldrich) radical을 이용한 항산화 활성은 Blois (1958)의 방법을 약간 변형하여 사용하였다. $1 \mathrm{mM} \mathrm{DPPH}$ 용 액 $100 \mu \mathrm{L}$ 와 추출물 $(12.5-400 \mu \mathrm{g} / \mathrm{mL})$ 을 $100 \mu \mathrm{L}$ 씩 취하여 혼 합한 후 $30 \mathrm{~min}$ 암 상태에서 방치한 후 잔존 radical 농도를 SpectraMAX 190 Microplate Reader (Molecular Devices, USA) 를 이용하여 $517 \mathrm{~nm}$ 에서 측정하였다. 활성 비교를 위하여 항산 화 물질로 잘 알려진 butylated hydroxyanisole (BHT), ascorbic acid (vitamin C)와 비교하였다. 전자공여능(\%)은 [1-(시료의 흡 광도/대조군의 흡광도)] $\times 100$ 에 의하여 산출하였다.

\section{MTT assay를 이용한 세포독성 측정}

B16F10 melanoma 세포와 RAW 264.7 대식세포 그리고 HDF 세포의 생존율 측정은 Mosmann (1983) 방법에 의하여 실시하 였다. 96-well plate의 각 well에 logarithmic phase에 도달한 세포를 $1 \times 10^{5}$ cells/well의 농도가 되도록 조절하여 분주하고, $24 \mathrm{~h}$ 배양하여 부착화 및 안정화를 시행하였다. $24 \mathrm{~h}$ 배양이 끝 난 후 추출물을 최종 농도 5-200 $\mu \mathrm{g} / \mathrm{mL}$ 가 되도록 배양액에 희 석하여 부착 및 안정화된 세포에 공급하고 24-48 h 동안 배양하 였다. 배양완료 후 각 well에 3-(4,5-Dimethylthiazol-2-yl)2,5-diphenyltetrazolium bromide (MTT) 용액 $(5 \mathrm{mg} / \mathrm{mL}$ in phosphate buffered saline)을 $10 \mu \mathrm{L}$ 씩 가해주고, 다시 $37^{\circ} \mathrm{C}, 5 \%$ $\mathrm{CO}_{2}$ 의 습윤 배양기에서 $4 \mathrm{~h}$ 동안 반응하여 MTT가 환원되도록 하 였다. 각 well에 생성된 formazan 결정을 dimethyl sulfoxide 150 $\mu \mathrm{L}$ 로 잘 녹여서 SpectraMAX 190 Microplate Reader를 이용하여 $540 \mathrm{~nm}$ 에서 흡광도를 측정하였다.

\section{B16F10 melanoma 세포에서 tyrosinase 저해활성 및 melanin 저해율 측정}

Tyrosinase 저해활성 측정은 B16F10 melanoma 세포를 24-well plate에 각 well 당 $1 \times 10^{5}$ cells/well을 가하여 배양 기에서 $24 \mathrm{~h}$ 동안 배양하여 안정화시켰다. 배양 후 아로니아 잎 추출물을 농도 별로 처리하여 $48 \mathrm{~h}$ 배양한 후 배지를 PBS로 2 번 세척하였다. $1 \%$ (W/V) Triton X-100 (Sigma-Aldrich)을 $10 \mathrm{mM}$ sodium phosphate buffer $\mathrm{pH}$ 6.8로 만들어 $150 \mu \mathrm{L}$ 로 세포를 모은 다음에 $2000 \mathrm{rpm}$ 에서 $5 \mathrm{~min}$ 원심분리 해서 각각 의 상층액 $40 \mu \mathrm{L}$ 에 기질인 3,4-dihydroxy-L-phehylalanine
(L-DOPA; Sigma-Aldrich) $200 \mu \mathrm{L}$ 을 가해 $37^{\circ} \mathrm{C}$ 에서 $1 \mathrm{~h}$ 배 양하였다. SpectraMAX 190 Microplate Reader를 이용하여 dopa chrome의 양을 $490 \mathrm{~nm}$ 에서 흡광도 측정하였다.

Melanin 저해율은 원심 분리한 pellet을 이용하여 농도 별로 $1 \mathrm{~N} \mathrm{NaOH} 100 \mu \mathrm{L}$ 에 증류수 $200 \mu \mathrm{L}$ 를 가해서 $60^{\circ} \mathrm{C}$ 에서 $1 \mathrm{~h}$ 배 양한 다음 완전히 녹인 후, SpectraMAX 190 Microplate Reader 를 이용하여 $405 \mathrm{~nm}$ 에서 흡광도를 측정하였다.

\section{8. $\alpha-\mathrm{MSH}$ 유도에 의한 tyrosinase 저해활성 및 melanin 저해율 측정}

외부자극에 따른 B16F10 melanoma 세포 내 tyrosinase의 활성 및 과생성 멜라닌에 아로니아 잎 추출물이 영향을 미치는 지 알아보기 위해 외부자극제로 $\alpha-\mathrm{MSH}$ (Sigma-Aldrich) 0.5 $\mathrm{mM}$ 을 사용하였다. 24-well plate에 각 well당 세포를 $1 \times 10^{5}$ cells/well로 접종한 후 $37^{\circ} \mathrm{C}, 5 \% \mathrm{CO}_{2}$ incubator에서 $24 \mathrm{~h}$ 동 안 배양을 하였다. 배지를 제거하고 아로니아 잎 추출물 20,50 , $100 \mu \mathrm{g} / \mathrm{mL}$ 농도로 전 처리하고 $1 \mathrm{~h}$ 후 $\alpha-\mathrm{MSH}(0.5 \mathrm{mM})$ 를 세포에 처리하여 $48 \mathrm{~h}$ 배양 후, tyrosinase 활성도 및 과생성 멜 라닌의 생성량을 측정함으로써 외부자극제에 따른 멜라닌화에 대한 추출물의 영향을 알아보았다.

\section{Nitrite 양의 측정}

RAW 264.7 대식세포로부터 생성된 NO의 양은 Griess (Sigma-Aldrich) 시약을 이용하여 세포배양액 중에 존재하는 $\mathrm{NO}_{2}{ }^{-}$의 형태를 측정하였다. 96-well plate에 각 well당 $1 \times 10^{5}$ cells/mL의 RAW 264.7 대식세포가 들어있는 부유액 $100 \mu \mathrm{L}$ 를 접종하고, $24 \mathrm{~h}$ 배양한 후 배지를 제거하고, 무혈청 배지에 최종 농도가 각각 $5,10,20,50 \mu \mathrm{g} / \mathrm{mL}$ 으로 되도록 시료를 처리한 후 염증 반응 유도 인자인 LPS $1 \mu \mathrm{g} / \mathrm{mL}$ 를 처리하여 $24 \mathrm{~h}$ 배양 하였다. 세포배양 상등액과 동량의 griess 시약을 혼합하여 96well plate에서 $10 \mathrm{~min}$ 동안 반응시킨 후, SpectraMAX 190 Microplate Reader를 사용하여 $540 \mathrm{~nm}$ 에서 흡광도를 측정하였 다. Nitrite의 농도는 sodium nitrite $\left(\mathrm{NaNO}_{2}\right)$ 와 비교하였다.

\section{ELISA kit를 이용한 콜라겐 합성량 측정}

Procollagen type I 콜라겐 합성량은 ELISA Kit (MK101; Takara Bio Inc., Japan)를 사용하여 측정하였다. $\mathrm{HDF}$ 세포를 24-well plate에 각 well당 $5 \times 10^{4}$ 개를 깔고, $10 \% \mathrm{FBS}$ 를 첨가 한 DMEM 배지에 추출물을 첨가하여 $48 \mathrm{~h}$ 동안 배양하고, 상층 액을 회수하였다. 그 후 회수된 상층액을 이용하여 Kit에서 제공 된 96-well plate에 coating하고, $4^{\circ} \mathrm{C}$ 에서 세척하여, $3 \%$ bovine serum albumin (BSA in TPBS)를 넣고 $2 \mathrm{~h}$ blocking 하였다. Primary antibody인 anti-collagen antibody를 $37^{\circ} \mathrm{C}$ 에서 90 $\min$ 처리한 후 TPBS로 3회 세척하였다. Secondary antibody 
인 anti-mouse IgG (whole mouse, alkaline phosphatase conjugated)를 $90 \mathrm{~min}$ 반응시킨 후 $\mathrm{TPBS}$ 로 3 회 세척하였 다. Alkaline phosphatease substrate solution [1 mg/ $\mathrm{mL}$ p-nutrophenyl phosphate (PNPP) in diethanolamine buffer)] 상온에서 $30 \mathrm{~min}$ 반응시킨 후 SpectraMAX 190 Microplate Reader를 이용하여 $405 \mathrm{~nm}$ 에서 흡광도를 측정하였 다.

\section{1. 통계분석}

본 연구의 모든 실험 결과는 3 회 이상 반복하여 평균값으로 결 과값을 도출하여 ANOVA 검정을 적용하였다. 대조군과 실험군 간의 결과는 mean \pm standard deviation $(\mathrm{M} \pm \mathrm{S} . \mathrm{D}$.)로 나타냈 으며 Student's $t$-test로 통계처리의 유의성을 검정하였다.

\section{Results and Discussion}

\section{1. 총 폴리페놀 및 플라보노이드 함량}

폴리페놀계 물질들은 식물체에 특수한 색깔을 부여하고 산화환 원반응에서 기질로 작용한다. 또한 폴리페놀계 물질들은 한 분자 내에 2 개 이상의 phenolic hydroxyl $(\mathrm{OH})$ 기를 가진 방향족 화합물 들을 가르키며, 플라보노이드와 탄닌이 주성분으로 충치예방, 고혈 압 억제, 항에이즈, 항산화, 항암 등의 다양한 생리활성을 가진다 (Park et al., 2008).

본 실험에서 사용한 아로니아 잎 에탄올, 열수 추출물 $1 \mathrm{mg} / \mathrm{mL}$ 농도에서 총 폴리페놀 함량은 tannic acid를 표준 곡선으로 하여 측 정한 결과, $167.46 \pm 1.03,79.04 \pm 1.01 \mu \mathrm{g} / \mathrm{mL}$ 으로 나타났다 (Table 1). 플라보노이드는 방향족 폴리페놀로서 크게 isoflavones, chalcones, flavanones, flavones, flavonols, flavanon-3-ols, anthocyanidins, flavan-3-ols, proanthocyanidins, flavans, flavan-3,4-diols 및 dihydrochalcones의 13 가지로 분류되며 생 체 내 산화작용을 억제한다고 알려져 있다. 이 성분은 항산화력을 나타내는 지표라고 할 수 있으며, 면역조절제로 사용되어 왔고, 최 근 항균작용, 항진균 바이러스작용, 혈관계 조절작용, 강장작용, 항 염증작용, 항암작용 등의 다양한 생리활성이 밝혀지고 있다(Kim \& Jang, 2016). Naringin을 표준 곡선으로 측정한 아로니아 잎 에탄 올, 열수 추출물 $1 \mathrm{mg} / \mathrm{mL}$ 농도에서 총 플라보노이드 함량은 각각 $105.15 \pm 1.22,52.21 \pm 1.13 \mu \mathrm{g} / \mathrm{mL}$ 로 나타났다(Table 1).

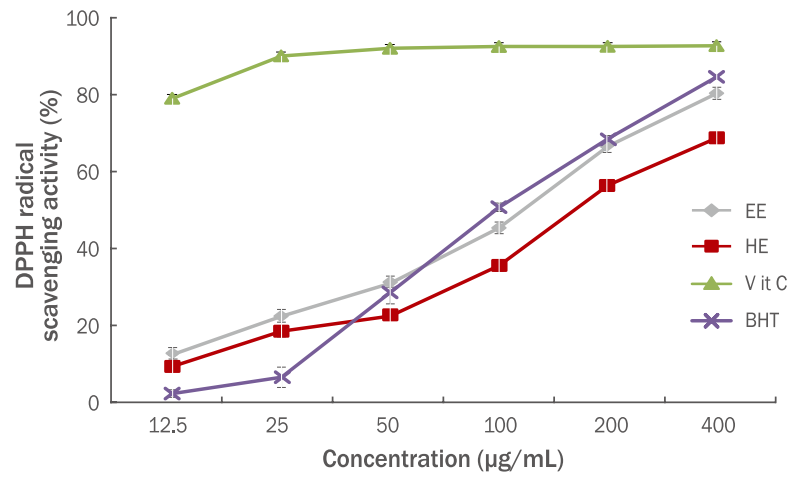

Figure 1. DPPH radical scavenging activities of $\boldsymbol{A}$. melanocarpa leaf extracts.

DPPH radical scavenging assays were conducted to investigate the anti-oxidant effects of $A$. melanocarpa leaf in $\mathrm{EE}$ and $\mathrm{HE}$ at varying concentration levels of $12.5,25,50,100,200$, and $400 \mu \mathrm{g} / \mathrm{mL}$, respectively. DPPH, 1,1-diphenyl-2-picrylhydrazyl; EE, 70\% ethanol extracts; $\mathrm{HE}$, hot water extracts; Vit C, ascorbic acid; $\mathrm{BHT}$, butylated hydroxytoluene group; $A$. melanocarpa, Aronia melanocarpa.

\section{DPPH radical 소거 활성}

$\mathrm{DPPH}$ 법은 항산화능을 측정하는 방법 중 하나로, $\mathrm{DPPH}$ 가 517 $\mathrm{nm}$ 에서 특이적인 흡수 band를 갖는 비교적 안정한 free radical이 라는 특성을 이용한다. 보라색의 $\mathrm{DPPH}$ 가 항산화능을 가진 물질로 부터 전자나 hydrogen radical을 받으면 환원되어 노란색으로 탈 색되고, 그 감소를 흡광도로 측정한다(Pak et al., 2016). 아로니 아 잎 에탄올, 열수 추출물을 농도 별(12.5-400 $\mu \mathrm{g} / \mathrm{mL}$ 로 DPPH 용액에 첨가하여 free radical 소거 활성 능력을 측정한 결과, 에탄 올 추출물은 $12.20,22.18,30.72,45.14,66.35,80.12 \%$ 의 소거 능이, 그리고 열수 추출물은 $9.12,18.28,22.24,35.34,56.25$, $68.52 \%$ 의 소거능이 확인 되었다(Figure 1 ).

\section{3. 아로니아 잎 추출물의 미백효과}

1) B16F10 melanoma 세포의 세포 생존율 분석결과

아로니아 잎 에탄올, 열수 추출물이 B16F10 melanoma 세포주의 세포 생존율에 미치는 영향을 알아보기 위하여 각각 $5,10,20,50$, $100,200 \mu \mathrm{g} / \mathrm{mL}$ 의 농도로 2 일 동안 처리하고 배양한 후 MTT 방 법으로 세포의 생존율을 관찰하였다. Figure 2에서 보는 바와 같이 대조군의 세포 생존율을 $100 \%$ 로 하였을 때, 아로니아 잎 추출물은 $100 \mu \mathrm{g} / \mathrm{mL}$ 이하 농도범위에서 $90 \%$ 이상의 생존율이

Table 1. Total polyphenol and flavonoid contents of $\boldsymbol{A}$. melanocarpa leaf extracts

\begin{tabular}{lll}
\hline & \multicolumn{1}{c}{$\mathrm{EE}$} & $\mathrm{HE}$ \\
Total polyphenol & $167.46 \pm 1.03 \mu \mathrm{g} / \mathrm{mL}$ & $79.04 \pm 1.01 \mu \mathrm{g} / \mathrm{mL}$ \\
Total flavonoid & $105.15 \pm 1.22 \mu \mathrm{g} / \mathrm{mL}$ & $52.21 \pm 1.13 \mu \mathrm{g} / \mathrm{mL}$ \\
\hline
\end{tabular}

A. melanocarpa, Aronia melanocarpa; $\mathrm{EE}, 70 \%$ ethanol extracts; $\mathrm{HE}$, hot water extracts. 


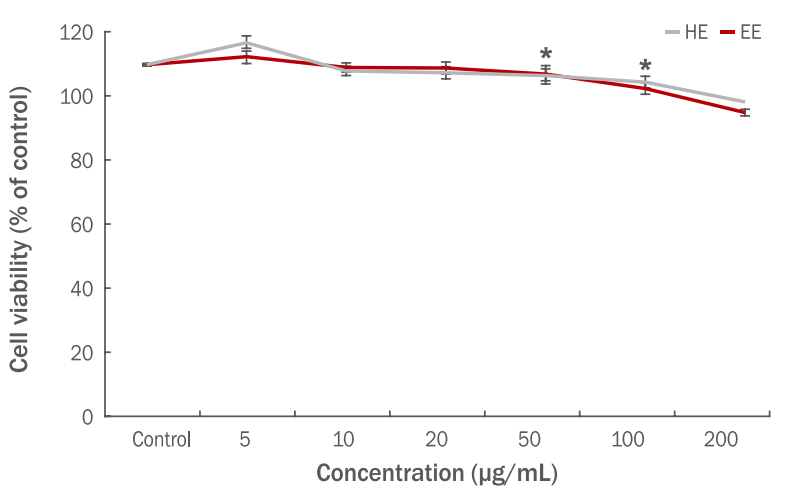

Figure 2. Effect of $\boldsymbol{A}$. melanocarpa leaf extracts on the cell viability of the mouse melanoma cell line B16F10.

B16F10 melanoma cells were incubated with $A$. melanocarpa leaf extracts at varying concentration levels $(5,10,20,50,100$, and $200 \mu \mathrm{g} / \mathrm{mL}$ ) for $24 \mathrm{~h}$ and cell viability was measured using the MTT assay. Values represent the $M \pm S$.D. of three independent experiments. Statistically significant differences are indicated with an asterisk ( ${ }^{*} p<0.05$, compared with untreated control cells). EE, $70 \%$ ethanol extracts; HE, hot water extracts; $A$. melanocarpa, Aronia melanocarpa; MTT, 3-(4,5-dimethylthiazol-2-yl)-2,5diphenyltetrazolium bromide; $\mathrm{M} \pm$ S.D., mean \pm standard deviation.

확인되었으므로 아로니아 잎 추출물 모두 $100 \mu \mathrm{g} / \mathrm{mL}$ 농도 범위 에서 세포독성을 보이지 않았다. 따라서 아로니아 잎 에탄올, 열 수 추출물 $5,10,20,50,100 \mu \mathrm{g} / \mathrm{mL}$ 농도에서 미백효과 측정 시 세포 사멸에 큰 영향을 주지 않는 것으로 분석되었다.

2) B16F10 melanoma 세포에서 tyrosinase 저해활성 및 melanin 저해율

피부는 자외선에 노출되면 tyrosine에서 출발하여 일련에 산화 중합 반응을 거쳐 생성된 melanin에 의해 기미, 노인성 홍반 등을 유발하며 피부 노화가 촉진된다. 이 과정에서 중요하게 작용하는 효 소가 tyrosinase이며, tyrosinase 효소의 억제는 멜라닌 생합성을 억제할 수 있는 것으로 알려져 있다(Kim et al, . 2011). 아로니아 잎 추출물의 B16F10 melanoma 세포의 세포내 tyrosinase 활성 저 해 효과를 측정한 결과 Figure 3 과 같다. 양성대조군인 arbutin은 $25 \%$ tyrosinase 활성이 저해 되었으며, 아로니아 잎 에탄올 추출물 과 열수 추출물은 $100 \mu \mathrm{g} / \mathrm{mL}$ 의 농도에서 각각 $21 \%, 18 \%$ 의 저해 활성이 확인되었고, $50 \mu \mathrm{g} / \mathrm{mL}$ 의 농도에서 각각 $18 \%, 4 \%$ 의 저해활 성이 확인되었다.

멜라닌 색소의 생합성은 tyrosinase 효소를 비롯하여 다양한 효소 들에 의해 조절되고 있어 아로니아 잎 에탄올, 열수 추출물의 멜라 닌 생합성 저해 정도를 확인한 결과 Figure 4 와 같다. 양성대조군인 arbutin은 멜라닌을 $28 \%$ 저해하였으며, 아로니아 잎 에탄올과 열수 추출물은 $100 \mu \mathrm{g} / \mathrm{mL}$ 의 농도에서 각각 멜라닌을 $24 \%, 18 \%$ 저해하 였고, $50 \mu \mathrm{g} / \mathrm{mL}$ 의 농도에서 각각 멜라닌을 $20 \%, 14 \%$ 저해하였다.

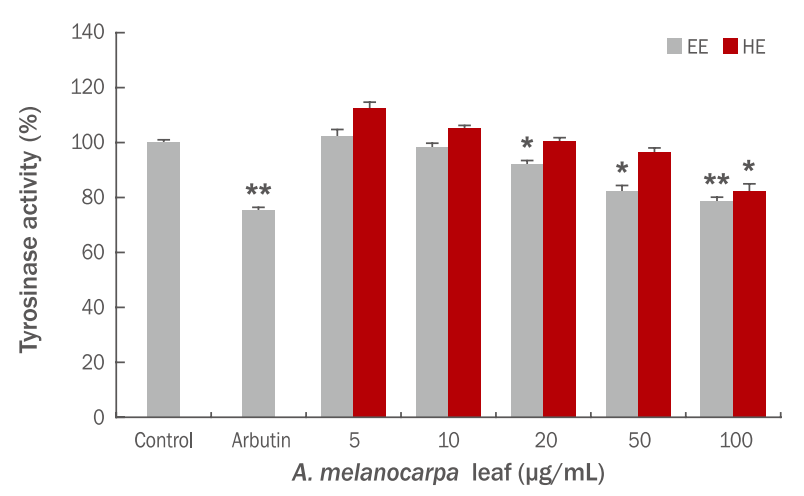

Figure 3. Inhibitory effect of $A$. melanocarpa leaf extracts on the tyrosinase activity in the mouse melanoma cell line B16F10.

B16F10 melanoma cells were seeded at $1 \times 10^{5}$ cells $/$ well. After $24 \mathrm{~h}$, cells were treated with varying concentrations of $A$. melanocarpa leaf extracts cultured for $48 \mathrm{~h}$. The tyrosinase activity was measured at $490 \mathrm{~nm}$. Arbutin $(250 \mu \mathrm{M})$ was used as a positive control. Values represent the $\mathrm{M} \pm \mathrm{S}$.D. of three independent experiments. Statistically significant differences are indicated with asterisks $\left({ }^{*} p<0.05,{ }^{* *} p<0.01\right.$ compared with untreated control cells). EE, $70 \%$ ethanol extracts; HE, hot water extracts; A. melanocarpa, Aronia melanocarpa; M \pm S.D., mean \pm standard deviation.

3) $\alpha-\mathrm{MSH}$ 유도에 의한 tyrosinase 저해활성 및 melanin 저해율

$\alpha-\mathrm{MSH}$ 는 melanocyte의 세포막에 존재하는 melanocortin 1 receptor $(\mathrm{MC} 1-\mathrm{R})$ 을 통해 adenylate cyclase를 활성화시켜 세포내 cyclic adenosine monophosphate (cAMP)의 양을 증 가시키고, 순차적으로 protein kinase A (PKA)를 활성화시켜 tyrosinase의 발현을 유도하거나 발현된 tyrosinase의 활성을 유 도하는 것으로 알려져 있다(Hong et al., 2005). 아로니아 잎 에 탄올, 열수 추출물이 $\alpha-\mathrm{MSH}$ 에 의해 유도된 $\mathrm{B} 16 \mathrm{~F} 10$ melanoma 세포의 tyrosinase 저해활성 및 melanin 합성에 미치는 영향 을 확인하기 위하여 $10,20,50,100 \mu \mathrm{g} / \mathrm{mL}$ 농도로 전 처리하 고 $1 \mathrm{~h}$ 후 $\alpha-\mathrm{MSH} 0.5 \mathrm{mM}$ 를 세포에 처리하여 $48 \mathrm{~h}$ 배양 후, tyrosinase 활성도 및 과생성 멜라닌의 생성량을 측정함으로써 외 부자극제에 따른 멜라닌화에 대한 추출물의 영향을 알아보았다.

실험 결과 B16F10 melanoma 세포에 $0.5 \mathrm{mM}$ 의 $\alpha-\mathrm{MSH}$ 를 투여하였을 때 대조군에 비하여 tyrosinase 활성도가 $81 \%$ 증가 하였다. 아로니아 잎 에탄올, 열수 추출물은 $100 \mu \mathrm{g} / \mathrm{mL}$ 처리시 $\alpha-\mathrm{MSH}$ 군에 비하여 tyrosinase 활성도가 각각 $51 \%, 36 \%$ 감소 하였으며, 양성대조군인 arbutin은 $61 \%$ 감소하였다(Figure 5).

Melanin 저해율 측정 결과, $\mathrm{B} 16 \mathrm{~F} 10$ melanoma 세포에 0.5 $\mathrm{mM}$ 의 $\alpha-\mathrm{MSH}$ 를 투여하였을 때 대조군에 비하여 멜라닌 생성 량이 $92 \%$ 증가하였다. 아로니아 잎 에탄올, 열수 추출물은 100 $\mu \mathrm{g} / \mathrm{mL}$ 처리시 $\alpha-\mathrm{MSH}$ 군에 비하여 각각 $63 \%, 54 \%$ 의 멜라닌 생성이 감소하였으며, 양성대조군인 arbutin은 $76 \%$ 감소하였다 (Figure 6). 


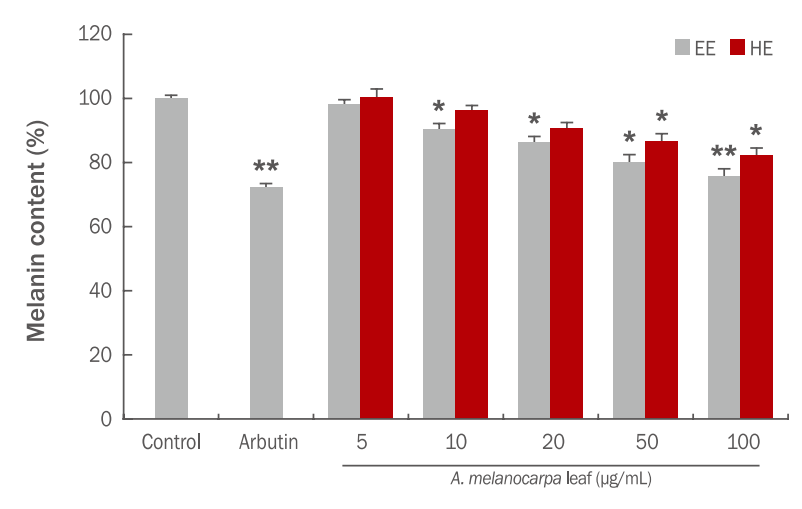

Figure 4. Effect of $\boldsymbol{A}$. melanocarpa leaf extracts on melanin synthesis in the mouse melanoma cell line B16F10.

B16F10 melanoma cells were seeded at $1 \times 10^{5}$ cells/well. After $24 \mathrm{~h}$, cells were treated with varying concentrations of $A$. melanocarpa leaf extracts cultured for $48 \mathrm{~h}$. The melanin content was measured at $405 \mathrm{~nm}$. Arbutin $(250 \mu \mathrm{M})$ was used as a positive control. Values represent the $\mathrm{M} \pm$ S.D. of three independent experiments. Statistically significant differences are indicated with asterisks $\left({ }^{*} p<0.05,{ }^{* *} p<0.01\right.$ compared with untreated control cells). EE, $70 \%$ ethanol extraction; HE, hot water extraction; $A$. melanocarpa, Aronia melanocarpa; M \pm S.D., mean \pm standard deviation.

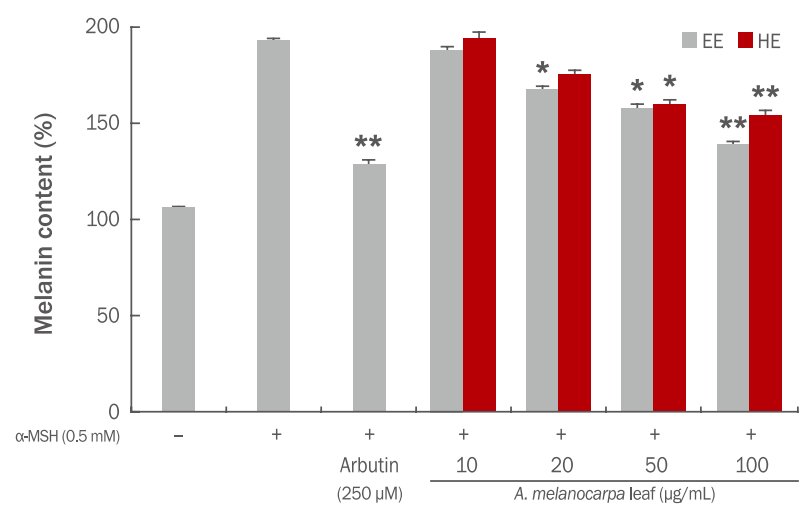

Figure 6. Inhibitory effect of A. melanocarpa leaf extracts on melanin synthesis in the mouse melanoma cell line B16F10 stimulated by $0.5 \mathrm{mM} \alpha-\mathbf{M S H}$.

B16F10 melanoma cells were seeded at $1 \times 10^{5}$ cells/well. After $24 \mathrm{~h}$, cells were treated with varying concentrations of $A$. melanocarpa leaf extracts and $\alpha-\mathrm{MSH}$ cultured for $48 \mathrm{~h}$. Melanin contents were measured at $405 \mathrm{~nm}$. Arbutin $(250 \mu \mathrm{M})$ was used as a positive control. Values represent the $\mathrm{M} \pm$ S.D. of three independent experiments. Statistically significant differences are indicated with asterisks $\left({ }^{*} p<0.05,{ }^{* *} p<0.01\right.$ compared with $\alpha-\mathrm{MSH}-$ treated cells). EE, 70\% ethanol extraction; $\mathrm{HE}$, hot water extraction; A. melanocarpa, Aronia melanocarpa; $\alpha-\mathrm{MSH}, \alpha$-melanocytestimulating hormone; $\mathrm{M} \pm$ S.D., mean \pm standard deviation.

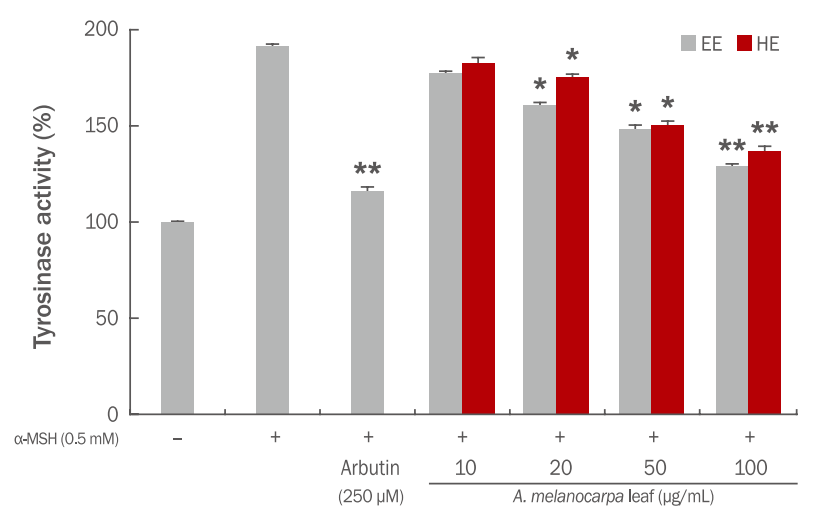

Figure 5. Inhibitory effect of $\boldsymbol{A}$. melanocarpa leaf extracts on tyrosinase activity in the mouse melanoma cell line B16F10 stimulated using $0.5 \mathrm{mM} \alpha-\mathbf{M S H}$.

B16F10 melanoma cells were seeded at $1 \times 10^{5}$ cells $/$ well. After $24 \mathrm{~h}$, cells were treated with varying concentrations of $A$. melanocarpa leaf and $\alpha-\mathrm{MSH}$ for $48 \mathrm{~h}$. Then, tyrosinase activity was measured at $490 \mathrm{~nm}$. Arbutin $(250 \mu \mathrm{M})$ was used as a positive control. Values represent the $\mathrm{M} \pm \mathrm{S}$.D. of three independent experiments. Statistically significant differences are indicated with asterisks $\left({ }^{*} p<0.05,{ }^{* *} p<0.01\right.$ compared with $\alpha-\mathrm{MSH}$ treated cells). EE, 70\% ethanol extracts; $\mathrm{HE}$, hot water extracts; $A$. melanocarpa, Aronia melanocarpa; $\alpha-\mathrm{MSH}, \alpha$-melanocyte-stimulating hormone; $\mathrm{M} \pm$ S.D., mean \pm standard deviation.

\section{4. 아로니아 잎 추출물의 항염증 효과}

1) 세포 생존율 분석결과

아로니아 잎 에탄올, 열수 추출물을 각각 $5-200 \mu \mathrm{g} / \mathrm{mL}$ 의 농 도로 Raw 264.7 대식세포에 처리하여 MTT assay를 진행한 결 과는 다음과 같다(Figure 7). 아로니아 잎 에탄올, 열수 추출물 은 $100 \mu \mathrm{g} / \mathrm{mL}$ 이하 농도범위에서 $90 \%$ 이상의 생존율이 확인되 었으므로 아로니아 잎 추출물 모두 $100 \mu \mathrm{g} / \mathrm{mL}$ 농도 범위에서 유 의할만한 세포독성을 보이지 않았다. 따라서 아로니아 잎 에탄올, 열수 추출물 5-100 $\mu \mathrm{g} / \mathrm{mL}$ 농도에서는 항염증 측정 시 세포사멸 에 큰 영향을 주지 않은 것으로 분석 되었다.

\section{2) Nitric oxide 생성억제 효과}

활성산소 중 하나이며, 최근 염증 유발에 중요한 역할을 하 는 것으로 알려진 nitric oxide (NO) 생성에 대한(Jeoung et al., 2009) 아로니아 잎 추출물의 효과를 알아보기 위하여 RAW 264.7 대식세포에 LPS로 자극을 주고, 아로니아 잎 에탄올, 열수 추출물을 처리하여 실험을 진행하였다. 생성된 $\mathrm{NO}$ 양은 griess 시 약을 이용하여 세포배양액 중에 존재하는 $\mathrm{NO}_{2}{ }^{-}$를 측정하여 확인 하였다. 아로니아 잎 추출물의 처리 농도는 세포 생존율 측정 결과 에 따라 세포에 영향을 미치지 않는 농도인 5-100 $\mu \mathrm{g} / \mathrm{mL}$ 로 처리 하였다. LPS $(1 \mu \mathrm{g} / \mathrm{mL})$ 처리 후 $\mathrm{NO}$ 의 생성량은 세포만 배양하 였을 때에 비하여 약 127 배 이상 증가되었다. 아로니아 잎 에탄올, 


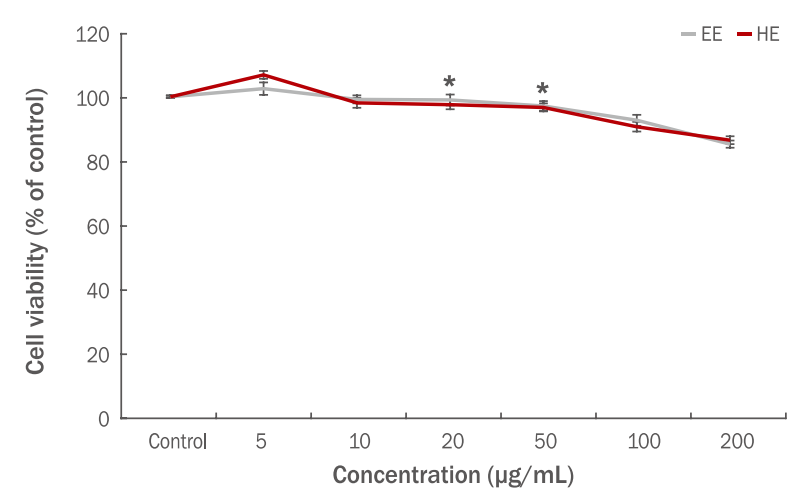

Figure 7. Effects of $A$. melanocarpa leaf extracts on the viability of RAW 264.7 cells.

RAW 264.7 cells were incubated with $A$. melanocarpa extracts at varying concentration levels $(5,10,20,50,100$, and $200 \mu \mathrm{g} /$ $\mathrm{mL}$ ) for $24 \mathrm{~h}$. Values represent the $\mathrm{M} \pm \mathrm{S}$.D. of three independent experiments. Statistically significant differences are indicated with an asterisk ( ${ }^{*} p<0.05$, compared with control). EE, $70 \%$ ethanol extracts; HE, hot water extracts; $A$. melanocarpa, Aronia melanocarpa; $\mathrm{M} \pm$ S.D., mean \pm standard deviation.

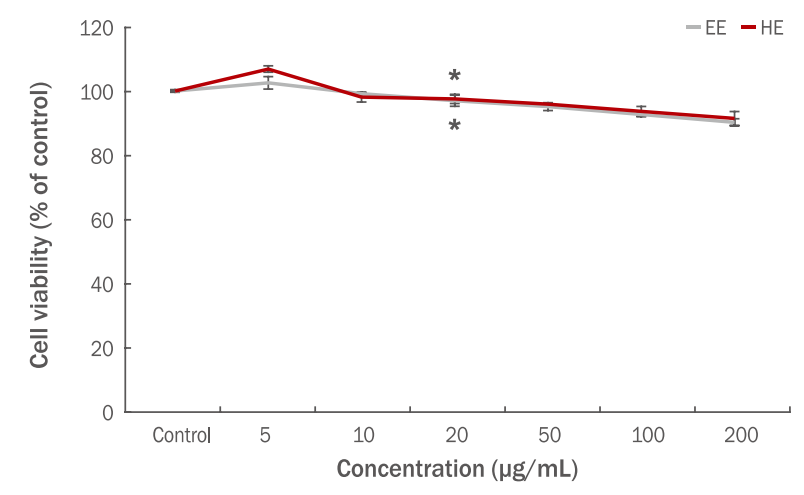

Figure 9. Effects of $\boldsymbol{A}$. melanocarpa leaf extracts on the viability of HDF cells.

Human dermal fibroblasts were incubated with $A$. melanocarpa leaf extracts at varying concentration levels $(5,10,20,50,100$, and $200 \mu \mathrm{g} / \mathrm{mL}$ ) for $48 \mathrm{~h}$ and cell viability was measured using MTT assay. Results are represented as M \pm S.D. of the three independent experiments. Statistically significant differences are indicated with an asterisk ( ${ }^{*} p<0.05$, compared with control). EE, $70 \%$ ethanol extraction; $\mathrm{HE}$, hot water extraction; $A$. melanocarpa, Aronia melanocarpa; MTT, 3-(4,5-Dimethylthiazol-2-yl)-2,5diphenyltetrazolium bromide; $\mathrm{M} \pm$ S.D., mean \pm standard deviation.

열수 추출물은 $100 \mu \mathrm{g} / \mathrm{mL}$ 농도에서 각각 $8.15,10.25 \mu \mathrm{M} \mathrm{NO}$ 생성량이 측정되어, $\mathrm{NO}$ 생성 억제에 따른 높은 항염증 활성을 가 지는 것을 알 수 있었다(Figure 8).

\section{5. 아로나이 잎 추출물의 주름개선 효과}

1) 세포 생존율 분석결과

아로니아 잎 에탄올, 열수 추출물을 각각 $5-200 \mu \mathrm{g} / \mathrm{mL}$ 의 농

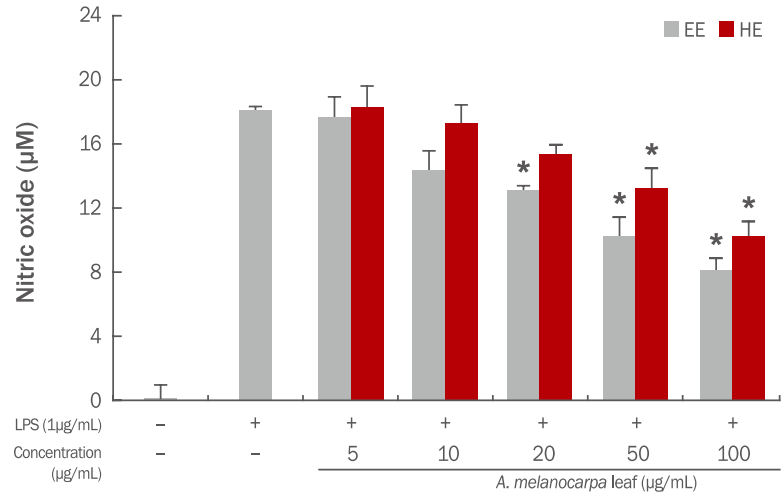

Figure 8. Effects of $A$. melanocarpa leaf extracts on NO production in LPS-stimulated RAW 264.7 cells.

RAW 264.7 cells were treated with varying concentrations of $A$. melanocarpa leaf extracts for $1 \mathrm{~h}$, and stimulated with or without LPS $(1 \mu \mathrm{g} / \mathrm{mL})$ for $24 \mathrm{~h}$. NO concentration in the medium was determined using Griess assay. Results are represented as $\mathrm{M} \pm \mathrm{S}$. D. of the three independent experiments. Statistically significant differences are indicated with asterisks $\left({ }^{*} p<0.05,{ }^{* *} p<0.01\right.$, compared with control). EE, $70 \%$ ethanol extracts; $\mathrm{HE}$, hot water extracts; LPS, lipopolysaccharide; $A$. melanocarpa, Aronia melanocarpa; NO, nitric oxide; M \pm S.D., mean \pm standard deviation.

도로 HDF 세포에 처리하여 MTT assay를 진행한 결과는 다음과 같다(Figure 9). 아로니아 잎 에탄올, 열수 추출물은 모든 농도에 서 $90 \%$ 이상의 생존율이 확인되었으므로 아로니아 잎 추출물 모 두 $200 \mu \mathrm{g} / \mathrm{mL}$ 농도 범위에서 유의할만한 세포독성을 보이지 않 았다. 따라서 아로니아 잎 에탄올, 열수 추출물 5-200 $\mu \mathrm{g} / \mathrm{mL}$ 농 도에서 procollagen 합성 실험을 진행하였다.

\section{2) Procollagen의 합성량 측정}

피부의 대표적인 탄력 섬유인 콜라겐(collagen)은 엘라스 틴(elastin)과 함께 망상으로 조직되어, 약 1,500 개 정도의 아미노산으로 구성된 독특한 삼중 나선 구조를 이루고 있다. 이 들 섬유아조직 아미노산은 과도하게 생성된 활성산소 종으로 인 하여 콜라겐과 엘라스틴 등의 탄력섬유에 지질 과산화가 일어나 비정상적인 교차결합 및 사슬절단이 발생하게 되므로 표면적 노 화현상을 나타내게 된다(Yang, 2012). 콜라겐은 피부에서 주름 형성과 밀접한 연관이 있다고 알려져 있고 콜라겐이 부족할 경 우 주름을 유발할 수 있다. 콜라겐은 전구물질인 procollagen 의 형태로 합성되며, 콜라겐 중합반응 시 콜라겐 분자로부터 절 단 및 분리된다고 알려져 있다. 즉 프로펩타이드의 양을 측정하 여 세포내에서의 콜라겐 생합성 정도를 파악할 수 있다(Lee et al., 2015). 콜라겐의 합성량 측정은 $\mathrm{HDF}$ 세포에 아로나아 잎 에탄올, 열수 추출물을 처리하여 procollagen type I C-peptide (PICP)의 함량을 ELISA kit를 이용하여 측정하였다. 그 결과 는 Figure 10과 같다. Transforming growth factor beta 1 


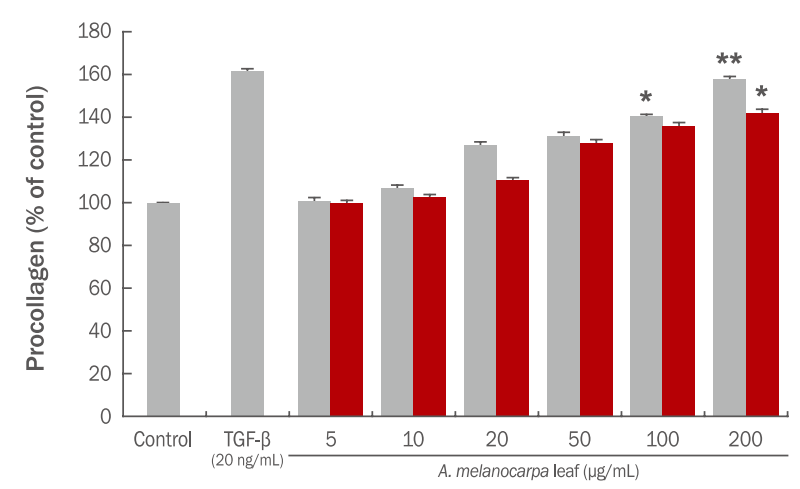

Figure 10. Effects of $A$. melanocarpa leaf extracts on procollagen synthesis in HDF cells.

Human dermal fibroblasts were treated with $A$. melanocarpa leaf extracts for $48 \mathrm{~h}$, and procollagen synthesis was determined as described in Materials and Methods. TGF- $\beta(20 \mathrm{ng} / \mathrm{mL})$ was used as a positive control. Values represent the $\mathrm{M} \pm$ S.D. of three independent experiments. Statistically significant differences are indicated with asterisks $\left({ }^{*} p<0.05,{ }^{* *} p<0.01\right.$, compared with untreated control cells). EE, 70\% ethanol extracts; $\mathrm{HE}$, hot water extracts; TGF- $\beta$, transforming growth factor beta $1 ; A$. melanocarpa, Aronia melanocarpa; HDF, human dermal fibroblasts; M \pm S.D., mean \pm standard deviation.

(TGF- $\beta) 20 \mathrm{ng} / \mathrm{mL}$ 로 처리하였을 경우 음성 대조군에 비해 procollagen 합성이 $62 \%$ 증가 하였으며, 아로니아 잎 에탄올, 열수 추출물 $200 \mu \mathrm{g} / \mathrm{mL}$ 로 처리하였을 경우 procollagen 합성 이 각각 $58 \%, 41 \%$ 증가하였다. 아로니아 잎 추출물은 양성대조 군 보다는 낮은 procollagen 합성이 확인 되었지만 $\mathrm{HDF}$ 세포의 procollagen 합성이 증가함을 확인 할 수 있었다.

\section{Conclusion}

본 연구는 아로니아 잎을 $70 \%$ 에탄올 및 열수로 추출하여 기 능성 화장품 소재로서의 가능성을 확인하고자 하였다. 추출물의 항산화 효과를 확인하기 위하여 총 폴리페놀과 총 플라보노이드 함량을 측정하였으며, DPPH radical 소거 활성을 측정하였다. B16F10 mouse melanoma 세포주를 사용하여 미백효과를 측정 하였다. 마우스의 RAW 264.7 대식세포에 LPS를 처리하여 NO 억제 효과를 확인 하였으며, HDF 세포에서 ELISA kit를 이용하 여 콜라겐 합성량을 측정하였다.

아로니아 잎 에탄올 추출물과 열수 추출물의 총 폴리페놀과 총 플라보노이드 함량을 측정한 결과, 에탄올 추출물에서 각각 $167.46 \pm 1.03$ (총 폴리페놀), $105.15 \pm 1.22$ (총 플라보노이드) $\mu \mathrm{g} / \mathrm{mL}$ 으로 높게 나타났으며, DPPH radical 소거 활성에서도 에 탄올 추출물이 $400 \mu \mathrm{g} / \mathrm{mL}$ 의 농도에서 $80.12 \%$ 의 소거능이 확인
되었다. 아로니아 잎 추출물이 B16F10 세포에 미치는 영향을 분 석하기 위해 세포 생존율을 측정한 결과, $100 \mu \mathrm{g} / \mathrm{mL}$ 이하의 농 도에서는 $90 \%$ 이상의 생존율이 확인되어 $5,10,20,50,100$ $\mu \mathrm{g} / \mathrm{mL}$ 농도에서 미백효과를 측정하였다. 아로니아 잎 에탄올 추 출물 $100 \mu \mathrm{g} / \mathrm{mL}$ 농도에서 tyrosinase 저해활성 및 멜라닌 생성 저해율은 $21 \%, 24 \%$ 의 효과가 확인 되었다. $\alpha-\mathrm{MSH}$ 유도에 의한 tyrosinase 저해활성 및 멜라닌 생성 저해율도 아로니아 에탄올 추출물이 효과가 더 높게 확인되었다.

RAW 264.7 대식세포에 독성을 미치지 않은 $100 \mu \mathrm{g} / \mathrm{mL}$ 이하 의 농도로 NO 생성 억제 효과를 측정한 결과, 아로니아 잎 에탄 올 추출물이 열수 추출물 보다 높게 $\mathrm{NO}$ 생성을 감소시키는 것으 로 나타났다. 아로나이 잎 에탄올, 열수 추출물은 $200 \mu \mathrm{g} / \mathrm{mL}$ 농 도에서 각각 $58 \%, 41 \%$ 의 procollagen 합성이 증가하여 양성대 조군 보다는 낮은 procollagen 합성이 확인되었지만 $\mathrm{HDF}$ 세포에 서 procollagen 합성을 증가하는 효과를 확인 할 수 있었다.

이상의 결과를 통해 아로니아 잎은 에탄올 추출물이 열수 추출 물 보다 항산화, 미백, 항염증 효과가 우수하였고 그리고 콜라겐 합성 효과를 확인되어, 기능성 화장품 소재로서의 활용가능성을 제시 할 수 있었다.

\section{References}

Blois MS. Antioxidant determinations by the use of a stable free radical. Nature, 181: 1199-1200, 1958.

Folin O, Denis W. A colorimetric method for the determination of phenols (and phenol derivatives) in urine. Journal of Biological Chemistry, 22: 305-308, 1915.

Hong SH, Roh SS. Effects of herbal extracts on the inflammatory reactions which use the makeup preparations. Journal of Physiology \& Pathology in Korean Medicine, 19: 1419-1426, 2005.

Hong US, Lee JH, Choi BT, Yoon HJ, Ko WS. Effects of aqueous extracts from Angelica dahurica Benth. on $\alpha$-melanocyte stimulating hormone-induced melanogenesis in B16 mouse melanoma cell. The Journal of Korean Oriental Medical Ophthalmology \& Otolaryngology \& Dermatology, 18: 1-12, 2005.

Hwang ES, Thi ND. Antioxidant contents and antioxidant activities of hot-water extracts of Aronia (Aronia melancocarpa) with different drying methods. Korean Journal of Food Science and Technology, 46: 303-308, 2014.

Jeong JM. Antioxidative and antiallergic effects of Aronia 
(Aronia melanocarpa) extract. Journal of the Korean Society of Food Science and Nutrition, 37: 1109-1113, 2008.

Jeoung YJ, Choi SY, An CS, Jeon YH, Park DK, Lim BO. Comparative effect on anti-inflammatory activity of the Phellinus linteus and Phellinus linteus grown in germinated brown rice extracts in murine macrophage RAW 264.7 cells. Korean Journal of Medicinal Crop Science, 17: 97-101, 2009.

Kang HC, Cha MY, Kim JY. A study of the antioxidant activities and whitening activities of Areca semen extracts as cosmetic ingredient. Journal of the Society of Cosmetic Scientists of Korea, 41: 269-277, 2015.

Kim JY, Park $\mathrm{CH}$. Hair dyeing properties using extracts of Aronia melancocarpa. Asian Journal of Beauty and Cosmetology, 12: 663-668, 2014.

Kim SH, Jang HJ. Study on the bioactive characteristics of Morinda citrifolia as a cosmetic raw material. Journal of the Society of Cosmetic Scientists of Korea, 42: 183-193, 2016.

Kim TH, Kim JM, Baek JM, Kin TW, Kim DJ, Park JH, Choe M. Antioxidant and whitening effects of Agrimonia pilosa Ledeb water extract. Korean Journal of Medicinal Crop Science, 19: 177-184, 2011.

Kim NY, Lee JM, Lee JY, Lee HY. Enhancement of anti-obesity activities of Aronia melanocarpa Elliot extracts from low temperature ultrasonification process. Korean Journal of Medicinal Crop Science, 24: 309-316, 2016.

Kim NY, Kim JH, Choi GP, Lee HY. Comparison of anti-skin wrinkle activities of Aronia melanocarpa extracts by extraction methods. Korean Journal of Medicinal Crop Science, 22: 217-222, 2014.

Lee MK, Kim DH, Park TS, Son JH. Antioxidant and antiwrinkling effects of extracts from Vitex trifolia L. Journal of Applied Biological Chemistry, 58: 125-129, 2015.

Lee SJ, Bu HJ, Lee JA, Jung DS. Screening of plants in Jeju for whitening materials in cosmeceutical. Journal of the Society of Cosmetic Scientists of Korea, 31: 115-119, 2005.

Lee JY, Ahn EK, Ko HJ, Cho YR. Ko WC, Jung YH, Choi KM, Choi MR, Oh JS. Anti-melanogenic, anti-wrinkle, antiinflammatory and anti-Oxidant effects of Xylosma congesta leaf ethanol extract. Journal of Applied Biological Chemistry, 57: 365-371, 2014.

Lee HM, Kong BJ, Kwon SS, Kim KJ, Kim HS, Jeon SH, Ha JH, Kim JS, Park SN. Antioxidative activities of Aronia melanocarpa fruit and leaf extracts. Journal of the Society of Cosmetic Scientists of Korea, 39: 337-345, 2013.

Lee SG. Preference evaluation of high functional spelt flour bread added with Aronia powder. Culinary Science \& Hospitality Research, 23: 181-188, 2017.

Mosmann T. Rapid colorimetric assay for cellular growth and survival: application to proliferation and cytotoxicity assays. Journal of Immunological Methods, 65: 55-63, 1983.

Pak WM, Kim KBWR, Kim MJ, Park JH, Bae NY, Park SH, Ahn DH. Anti-melanogenesis and anti-wrinkle effects of Sargassum micracanthum extracts. Microbiology and Biotechnology Letters, 44: 19-25, 2016.

Park KB, Kwon SY, Moon JH. Quality characteristics of Aronia (Aronia melanocarpa) juice added yogurt dressing. Culinary Science \& Hospitality Research, 21: 206-217, 2015.

Park JM, Lee JY, Park TS, Hyun SJ, Kim HH, Cho YJ, Kwon OJ, Son AR, Kim DS, An BJ. A study on the cosmeceutical activities of Prunus sargentii R. Applied Biological Chemistry, 51: 70-78, 2008.

Shin D, Choe T. Study on the bioactive characteristics of Aronia extract as a cosmatic raw material. Asian Journal of Beauty and Cosmetology, 13: 275-283, 2015.

Yang JC. The evaluation on the effectiveness as a cosmetic material of oil extracted from Schizandra chinensis seed. Journal of Oil \& Applied Science, 29: 231-237, 2012.

Yang WT. Kim KS, Kwon YS, Kim DH, Kim DH. Whitening and anti-aging effects of Cistanche deserticola extract. Journal of Plant Biotechnology, 43: 492-499, 2016.

Yang $\mathrm{H}$, Oh KH, Yoo YC. Anti-inflammatory effect of hot water extract of Aronia fruits in LPS-stimulated RAW 264.7 macrophages. Journal of the Korean Society of Food Science and Nutrition, 44: 7-13, 2015.

Yu JM, Kim DH, Son JH. Whitening effects of solvent fractions isolated from Vitex rotundifolia. Journal of Applied Biological Chemistry, 58: 266-271, 2015. 


\section{국문초록}

\section{아로니아 잎 추출물을 이용한 화장품 소재 개발}

이정민, 유민정

남부대학교 향장미용학과, 광주, 한국

목적: 아로니아 잎 추출물의 화장품 기능성 소재로서 활용 가능성을 알아보기 위하여 항산화, 미백, 항염증, collagen 합성량을 측 정하였다. 방법: 아로니아 잎을 에탄올, 열수 추출하여 시료로 사용하였다. 1,1-diphenyl-2-picrylhydrazyl (DPPH) 소거능과 총 폴리페놀 함량, 총 플라보노이드 함량을 측정하였으며, B16F10 mouse melanoma 세포주를 사용하여 미백효과를 측정하였다. 마 우스의 RAW 264.7 대식세포에 lipopolysaccharide (LPS)를 처리하여 nitric oxide (NO) 억제 효과를 확인 하였으며, human dermal fibroblast $(\mathrm{HDF})$ 에서 ELISA kit를 이용하여 procollagen 합성량을 측정하였다. 결과: 아로니아 잎 에탄올, 열수 추출물의 총 폴리페 놀 함량은 $167.46 \pm 1.03,79.04 \pm 1.01 \mu \mathrm{g} / \mathrm{mL}$ 으로 확인되었으며, 총 플라보노이드 함량은 $105.15 \pm 1.22,52.21 \pm 1.13 \mu \mathrm{g} / \mathrm{mL}$ 로 나타났다. DPPH radical 소거능은 아로니아 에탄올 추출물의 효과가 높게 확인되었다. B16F10 세포에서 아로니아 잎의 tyrosinase 저해활성 및 melanin 저해율의 경우, 에탄올 추출물이 $100 \mu \mathrm{g} / \mathrm{mL}$ 농도에서 $21 \%, 24 \%$ 의 저해 효과가 확인되었으며, 열수 추출 물은 $18 \%, 18 \%$ 의 저해 효과가 확인되었다. $\alpha$-melanocyte-stimulating hormone ( $\alpha-\mathrm{MSH})$ 유도에 의한 tyrosinase 저해활성 및 melanin 저해율도 아로니아 에탄올 추출물의 효과가 더 높게 확인되었다. 아로니아 잎의 항염증 효과는 에탄올 추출물의 NO 생성 억제능이 더 우수하였다. 아로나이 잎 에탄올, 열수 추출물의 $200 \mu \mathrm{g} / \mathrm{mL}$ 농도에서 각각 $58 \%, 41 \%$ 의 procollagen 합성이 증가하여 양성대조군 보다는 낮은 procollagen 합성이 확인 되었지만 $\mathrm{HDF}$ 세포에서 procollagen 합성을 증가시킴으로써 주름개선 효과를 가 지는 것을 확인 할 수 있었다. 결론: 이상의 결과를 통해 아로니아 잎은 에탄올 추출물이 열수 추출물 보다 항산화, 미백 그리고 항 염증 및 collagen 합성 효과가 더 우수하였으며, 기능성 화장품 소재로서의 활용 가능하리라고 생각된다.

핵심어: 아로니아, 항산화, 화장품, 항염, 미백

\section{참고문헌}

강희철, 차미영, 김재영. 화장품 소재로서 빈랑자의 항산화 및 미백활성에 관한 효과. 대한화장품학회지, 41: 269-277, 2015.

김남영, 김정환, 최근표, 이현용. 추출방법에 따른 아로니아 추출물의 주름 개선 효능 비교. 한국약용작물학회지, 22 : 217-222, 2014.

김남영, 이정민, 이재용, 이현용. 아로니아 저온 초음파 추출물의 항비만 활성 증진. 한국약용작물학회지, 24: $309-316$, 2016.

김주영, 박철호. 아로니아(Aronia melancocarpa) 추출물을 이용한 모발의 염색 특성. 아시안뷰티화장품학회지, 12 : 663-668, 2014.

김승희, 장혜진. 화장품 소재로서의 노니 추출물에 관한 특성연구. 대한화장품학회지, 42: 183-193, 2016.

김태혁, 김정미, 백종미, 김태우, 김대중, 박정해, 최면. 짚신나물 물 추출물의 항산화 활성 및 미백효과에 관한 연구. 한국 약용작물학회지, 19: 177-184, 2011.

박기봉, 권순용, 문정희. 아로니아즙 첨가량에 따른 요구르트 드레싱의 품질특성. 한국조리학회지, 21: 206-217, 2015. 박원민, 김꽃봉우리, 김민지, 박지혜, 배난영, 박선희, 안동현. 잔가시 모자반 추출물의 주름 개선 및 미백 효과. 한국미생 물·생명공학회지, 44: 19-25, 2016.

박정미, 이진영, 박태순, 현석준, 김한혁, 조영제, 권오준, 손애량, 김동석, 안봉전. 산벚나무(Prunus sargentii R.) 수피 의 화장품 활성에 관한 연구. 한국응용생명화학회지, $51: 70-78,2008$. 
신동화, 최태부. 화장품 소재로서 아로니아 추출물의 생리활성 연구. 아시안뷰티화장품학술지, 13: 275-283, 2015. 양원태, 김경숙, 권용삼, 김두현, 김도훈. 육종용 추출물의 미백과 항노화 효과. 식물생명공학회지, 43: 492-499, 2016. 양재찬. 오미자 씨 오일의 화장품 소재로서 유효성 평가. 오일 및 응용과학 학회지, 29: 231-237, 2012.

양혜, 오광훈, 유영춘. LPS 자극 RAW 264.7 대식세포에 있어서 아로니아 열매 열수 추출물의 항염증 효과. 한국식품영양 과학회지, 44: 7-13, 2015.

유재모, 김동희, 손준호. 만형자 용매 분획물의 미백 개선 효과. 한국응용생명화학회지, 58: 266-271, 2015.

이미경 김동희 박태순 손준호. 만형자 추출물의 항산화 및 주름개선 효과. 한국응용생명화학회지, 58: 125-129, 2015. 이선구. 아로니아를 첨가한 고기능성 스펠트 밀가루 식빵의 기호도 분석. 한국조리학회지, 23: 181-188, 2017. 이선주, 부희정, 이정아 정덕상. 제주산 식물을 이용한 미백 기능성화장품 원료에 대한 검색. 대한화장품학회지, $31:$ 115-119, 2005.

이재연, 안응경, 고혜진, 조영락, 고운철, 정용환, 최경민, 최미래, 오좌섭. 산유자 잎 에탄올 추출물의 미백, 주름억제, 항 염증 및 항산화 효능. 한국응용생명화학회지, 57: 365-371, 2014.

이혜미, 공봉주, 권순식, 김경진, 김해수, 전소하, 하지훈, 김진숙, 박수남. 아로니아 베리 열매 및 잎 추출물의 항산화 활 성. 대한화장품학회지, 39: 337-345, 2013.

정종문. 아로니아(Aronia melanocarpa)로 부터 유래한 추출물의 항산화 및 항알레르기 효능. 한국식품영양과학회지, 37: 1109-1113, 2008.

정용준, 최세영, 안치선, 전윤희, 박동기, 임병우. 상황버섯과 발아현미상황버섯 열수추출물의 Murin Macrophage RAW 264.7세포에서 항염증 반응 비교. 한국약용작물학회지, 17: 97-101, 2009.

홍석훈, 노석선. 색조화장품에 적용될 수 있는 17 종의 천연한약재가 피부염증억제에 미치는 임상적 연구. 동의생리병리학 회지, 19: 1419-1426, 2005.

황은선, 뉴안 도티. 건조방법에 따른 아로니아(Aronia melancocarpa) 열수 추출물의 항산화 성분 함량 및 항산화 활성. 한국식품과학회지, 46: 303-308, 2014.

홍의석, 이준혁, 최병태, 윤화정, 고우신. 白芷의 $\alpha$-Melanocyte Stimulating Hormone에 의해 유도된 B16 흑생종 세포 의 멜라닌 형성에 미치는 영향. 한방안이비인후피부과학회지, 18: 1-12, 2005. 


\section{中文摘要}

\section{黑果腺助花揪叶提取物作为化妆品原料的开发}

李鼎珉，柳敏貞“

南部大学香匠美容学科, 光州, 韩国

目的: 探索黑果腺肋花揪叶提取物用作化妆品原料的可行性, 并测定其抗氧化剂, 美白, 抗炎和胶原合成作 用。方法: 使用黑果腺肋花揪叶的乙醇和热水提取物作为测试样品, 测定其提取物的总多酚和类黄酮含量。使 用1,1-diphenyl-2-picrylhydrazyl（DPPH）自由基清除测定法测量其提取物的抗氧化活性。在小鼠黑素瘤细 胞系B16F10中，测量其提取物的美白作用。使用lipopolysaccharide（LPS）刺激的RAW264.7小鼠巨噬细 胞测量其提取物的nitric oxide（NO）抑制生成作用。利用ELISA kit在人皮肤成纤维细胞 (human dermal fibroblasts, HDF) 中测量其提取物的原胶原蛋白合成量。结果：黑果腺肋花揪叶乙醇和热水叶提取物的总 多酚含量分别为 $167.46 \pm 1.03 \mu \mathrm{g} / \mathrm{mL}$ 和 $79.04 \pm 1.01 \mu \mathrm{g} / \mathrm{mL}$, 总类黄酮含量分别为 $105.15 \pm 1.22 \mu \mathrm{g} / \mathrm{mL}$ 和 $52.21 \pm 1.13 \mu \mathrm{g} / \mathrm{mL}$ 。乙醇提取物的DPPH自由基清除作用高于热水提取物。在小鼠黑色素瘤细胞系B16F10 中, 酪氨酸酶抑制活性和黑色素抑制率结果显示: 使用 $100 \mu \mathrm{g} / \mathrm{mL}$ 乙醇提取物时, 分别为 $21 \%$ 和 $24 \%$; 使用 $100 \mu \mathrm{g} / \mathrm{mL}$ 热水提取物时，分别为 $18 \%$ 和 $18 \%$ 。 $\alpha$-melanocyte-stimulating hormone ( $\alpha$-MSH) 诱导的酪氨 酸酶抑制活性和黑素抑制在乙醇提取物中比在热水提取物中高。其提取物的抗炎作用结果显示, 乙醇提取物的 NO抑制作用高于热水提取物。黑果腺肋花揪叶乙醇和热水叶提取物在浓度为 $200 \mu \mathrm{g} / \mathrm{mL}$ 时, 其原胶原蛋白合 成量分别增加 $58 \%$ 和 $41 \%$ 。虽然其增加量低与阳性对照组，但在HDF细胞中增加了原胶原蛋白的合成，从而确 认了其䏢纹改善效果。结论: 通过以上的结果, 黑果腺肋花揪叶的乙醇提取物比热水提取物在抗氧化、美白、 抗炎、胶原合成等效果方面更为优秀，因此作为功能性化妆品原料充分具有可行性。

关键词: 黑果腺肋花揪，抗氧化，化妆品，抗炎，美白 